\title{
Student Investment Interest in Sharia Fintech
}

\author{
Novi Puspitasari ${ }^{1 *}$, Safira Meifindasari ${ }^{2}$, Ahmad Ahsin Kusuma M. ${ }^{3}$ \\ ${ }^{1}$ Faculty of Economics and Business, University of Jember, Jember, Indonesia \\ ${ }^{2}$ Faculty of Economics and Business, University of Jember, Jember, Indonesia \\ ${ }^{3}$ Faculty of Economics and Business, University of Jember, Jember, Indonesia \\ "Corresponding author. Email: novipuspitasari@ unej.ac.id
}

\begin{abstract}
Investment is the investment of resources or capital that is expected to generate profits in the future. Sophisticated sharia fintech, easy to use, and in accordance with Islamic sharia is the right choice for Muslim investors. This study is intended to analyze the effect of attitudes, subjective norms, and behavioral control based on Ajzen's theory, namely the theory of planned behavior on the investment interest of students who become investors in sharia fintech applications that are developing in Indonesia. This study used purposive sampling as the research sample. The sample criteria selected for the research sample are undergraduate students of the Faculty of Economics and Business at the University of Jember and are currently or have used sharia investment application products at least once. Questionnaires that have met the validity test requirements come from 97 respondents using Google Form. The test technique uses multiple linear regression analysis with SPSS 26 tools. The results show that subjective attitudes and norms have a positive effect on student investment interest in sharia fintech. While the results of behavioral control show a negative influence on student investment interest in sharia fintech.
\end{abstract}

Keywords: Investment, sharia fintech, theory of planned behavior.

\section{INTRODUCTION}

It is important to make investments early on so that a person can have productive assets without the need to own his own business to meet the growing needs and wants. Many Indonesian people already know the importance of investing. This is evidenced by the increase in the number of investors in the Indonesian capital market through out 2020. The number of capital market investors increased by $34.78 \%$ from 2,484,354 at the end of 2019 to $3,348,396$ investors as of October 16, 2020, based on data from PT. Indonesian Central Securities Depository.

According to the 2020 Kaleidoscope of Achievements published by KSEI, it is also stated that investors who are less than or equal to 30 years old hold the highest percentage of $54.79 \%$ with total assets of IDR 30.82 trillion [1]. The demographic data informs that the average Most investors in Indonesia are the younger generation. The President Director of KSEI, Uriep Budhi Prasetyo, also said that through these data, it can be concluded that around $70 \%$ of Indonesian capital market investors are at a young age. Students who are the younger generation in Indonesia can also be said that they have a higher increase in investment interest in 2020 [2].

In addition to investment interest, many technological innovations are also developing from day to day. Technology makes it easier for people to meet the needs of life, including the economic sector. Many economic sectors are starting to leave their traditional economic activities and switch to take advantage of technological sophistication. One of the technological sophistications in the economic field is financial technology. According to [3] that fintech is a financial innovation supported by information technology that generated in new business models, applications, processes, or products that have influence infinancial markets and financial institutions. Fintech currently used by many bank financial institutions and non-bank financial institutions to attract publicinterest so that they use the service for the short tolong term. Easy and fast services can be enjoyed by consumers in all conditions, including during the Covid-19 pandemic,which makes all people in theworld 
required to keep their distance and comply with health protocols.

The rapid development of investment interest in fintech in Indonesia, it can be measured by the theory that was coined by Ajzen who stated that a person's intention to be have is influenced by 3 components, namely attitudes, subjective norms, and perceptions of behavioral control [4]. This theory is called Theory of Planned Behavior which in this study measures the influence of attitudes, subjective norms, and behavioral control on student investment interest in fintech sharia. Undergraduate students of the Faculty of Economicsand Business, University of Jember became respondents in this study because the students are currently studying economics and business, including investment.

According to Hurlock in Mardison [5], students are college students who fall into the category of late teens, aged 18-21 years. Adolescent age according to [5] has a tendency to avoid rejection from peers or to conform or be the same as peers, so this study focuses on Islamic investments made by students who have become investors in fintech sharia, with a narrower research sample scope, namely students of the Faculty of Economics and Business, University of Jember. Behavior not investigated in this study so that it becomes a research limitation. Therefore, the the conceptual framework of this study is presented in Figure 1.

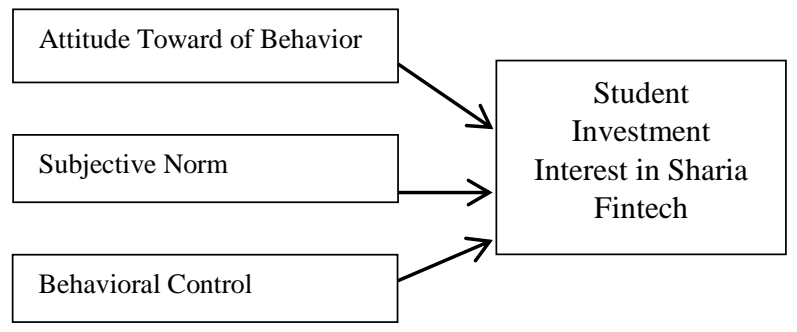

Figure 1 Conceptual Framework

\subsection{Theoretical Review}

\subsubsection{Sharia Investment}

Investment is an activity of placing funds in one or more types of assets during a certain period in the hope of earning income and/or increasing the value of investment in the future [6]. Investment can also be said as a number of funds or other resources that are committed by a person at this time with the aim of obtaining profits in the future [7].

Most of Indonesia's population embraces Islam so that everything that is done by Muslims in Indonesia is guided by the Qur'an, hadith, ijma' and qiyash including economic behavior. According to Sutedi, investment is a commitment to sacrifice a definite amount of funds in the present to gain profits in the future [8], so Islam strongly recommends investment both from an economic and non-economic perspective. This is because Islam commands His people to develop wealth and not accumulate it so that the wealth can be useful for themselves and others.

The concept of investment cannot be said to becontrary to Islamic sharia, investment can be carried out and does not cause sin if it is carried out inaccordance with Islamic sharia if its application is inaccordance with the concept of Islamic law. Because basically, economic activity is human nature. In the rules of fiqh it is stated that:

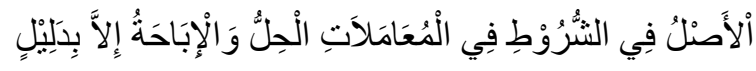

It means: "The basic principle of muamalah is that it is permissible unless there is evidence that forbids it"

Ahmad al-Haristi in Umar bin al-Khatab's book Economic Fiqh quoted [8] explained that Calipha Umar once advised Muslims to use their capital productively, "Whoever has money, let him invest it and whoever owns land, let him cultivate it". Thus, it can be concluded that in Islam the guidelines for investing are allowed and recommended, but must still be in accordance with Islamic sharia. In the teachings of Islam, investment has the main principle that it must be halal, tayyib, avoid the elements usury and not too much (israf). In addition, according to [8] investments that are often used by the public are not far from business transactions so that investment must also avoid riba, gharar, maysir and etc.

\subsubsection{Investment Interest}

[9] states that interest is a person's affective tendency to make choices of activities that are unstable due to certain conditions. Individual conditions can change a person's interest in something. Interest has a very big influence on the activities carried out by someone. According to [10], interest can arise because of the ability or experience related to objects, so that if someone has followed actions such as studying investment, then that person can arise interest in becoming an investor.

Kaleidoscope and 2021 Strategic Plan published by PT. The Indonesian Central Securities Depository (KSEI) which has a role as a Depository and Settlement Institution carries out various developments Indonesia's capital market infrastructure states that Indonesian investors in 2020 
will experience a considerable increase. The KSEI data mentions investor demographics based on gender, age, occupation, education, and income. The most interesting data is that most of the investors are young Indonesians with an age range of less than/equal to 30 years with a percentage of $54.79 \%$ as of December 28, 2020 [1].

This data show that the young generation in Indonesia has a high potential to improve the country's economy through investment. Although in terms of work, namely as students, they are the second largest investor after employees (private, state, and teachers) which is $27.19 \%$ as of December 28 2020 , so it can be concluded that students have a big role in increasing the number of investors in 2020. In this way, the investment interest of students in Indonesia also increases.

\subsubsection{Sharia Fintech}

Many economic sectors are starting to leave theirtraditional economic activities and switch to take advantage of technological sophistication. One of the technological sophistications in the economic field is financial technology (fintech). Pribadiono, Law, Esa \& West (2016) stated that Financial Technology (Fintech) is a combination of technology and financial features where there is innovation in the financial sector with modern technology. Meanwhile, according to Hsueh in [11] fintech is a new financial service developed through information technology innovation. Therefore, it can be concluded that fintech is financial services through technology.

Existence fintech in Indonesia is not only limited to conventional, but also fintech Sharia also began to be developed with the issuance of the fatwa of the National Sharia Council of the Indonesian Ulema Council (DSN-MUI) Number 117/DSN-MUI/II/2018 concerning Information Technology-Based Financing Services. The fatwa is the legal basis for fintech lending that run sharia products. The fatwa regulates transactions fintech in accordance with the contracts allowed in Islam. Since the issuance of the fatwa this, companies fntech began to register with the OJK.

Sharia investment products can be found in Islamic and non-bank financial institutions. The product can also be accessed through the application smartphones. In addition, in December 2017, fintech There are 10 sharia platforms listed. Company fintech lending Sharia ones registered with OJK as of 7 December 2020 are Investree (Conventional \& Sharia), Ammana, Sharia Fund, Alami, Duha Sharia, Qazwa, BSalam, Ethis, Kapitalboost, Papitupi Sharia, Finteck Sharia. Meanwhile, those who have obtained official business permits from the OJK are Investree, Ammana and Alami [12].

\subsubsection{Theory of Planned Behavior}

According to [4], a person's behavior depends on the desire to behave of his behavior. From the perspective of the theory proposed by Ajzen, it can be concluded that behavioral beliefs lead to positive or negative attitudes towards certain behaviors. Normative beliefs lead to the formation of perceptions of social pressure to take action, temporary control belief lead to perceptions of behavioral control [13]. Attitudes towards behavior, subjective norms, and perceptions of behavioral control when combined will result in the formation of behavioral intentions .

\subsubsection{Attitude Toward of Behavior}

Inner attitude theory of planned behavior what Ajzen put forward is explained as an evaluation of a person's positive and negative beliefs or feelings when he is about to perform a behavior [14]. According to [15], attitudes toward behavior are determined by beliefs about the consequences of that behavior which are also called behavioral beliefs. (behavior beliefs). This belief is related to the individual's subjective assessment of his surroundings based on his understanding of the individual and his environment which is carried out by linking certain behaviors with the benefits or losses that might be obtained if the individual does or does not.

The attitude of a Muslim towards a behavior has its own processes and principles, where the decisionmaking process of a Muslim begins with recognizing the problem, seeking information, and evaluating alternatives. The evaluation of this alternative consists of the rejection of harm, the perception of need in Islam, and the perception of mardhatillah or pleasure from Allah SWT. thus giving rise to a decision whether the decision to behave will be made or not [16]. Attitude components according to [14] there are 2 groups in attitude formation, namely:behavioral beliefs which is a person's belief in behavior and this belief will encourage the formation of attitudes, then evaluation of behavioral beliefs which is an individual's evaluation of the positive or negative of a behavior based on the individual's beliefs. The belief of a Muslim who makes the Koran as a way of life that he believes is certainly different from the beliefs of nonMuslims. Based on this evaluation and belief, one's attitude can be formed.

\subsubsection{Subjective Norm}

Individual perceptions of the expectations of people who influence their lives on whether or not to do a behavior are called subjective norms. As the 
name implies, this perception is subjective and influenced by beliefs. According to [16], several things that can influence subjective norms are family support, people who are considered important, and support from peers (friends and relatives).

[14] state that subjective norms have two components, namely normative beliefs and motivation to comply. Normative beliefs which are beliefs about other people towards someone who becomes a reference for behaving or not behaving. Norm beliefs relate to the opinions of influential figures or people in a person's life,so that it is their views that make that person do something or not do something. Temporary motivation to comply is a person's motivation to fulfill his expectations. There is encouragement from people around with the motivation to follow their views in doing or not doing something can shape decisions someone to behave. Both are indicators to determine the effect of subjective norms contained in this study.

\subsubsection{Behavioral Control}

In addition to subjective attitudes and norms, the last component of this theory is behavioral control. According to [4], behavioral control or commonly referred to asperceived behavioral control is an individual's perception of whether or not it is easy to realize a certain behavior. A person's belief that he has good competence is accompanied by with the facility can improve behavior control. In conditions of strong and convincing behavioral control, a person has clear information on the behavior in question, then he can practice so that it increases confidence in his abilities in the field, then this behavioral control strengthens motivation [15].

To measure behavior control, [17] suggests that behavioral control can be measured in two ways, namely by directly measuring a person's control in displaying certain behaviors, and by measuring someone's beliefs about their abilities and opportunities to display behavior. This study uses a second way to measure behavioral control, namely by measuring beliefs about the abilities and opportunities of students when they become investors in Indonesia fintech sharia.

\section{METHODOLOGY}

This study uses a quantitative method with an explanatory survey type which aims to obtain an overview of whether there is an influence between attitudes, subjective norms and behavioral control on student investment interest in fintech sharia. Source of data using primary data through questionnaires Google Forms. The data in this study were taken in
May, 2021 using a questionnaire in the form of a Google Form and distributed through social media, namely Whatsapp. Secondary data on this research use the data from website to determine the number of respondent populations and respondent's profile.

The sample in this study was taken using the purposive sampling with the criteria that the respondent is an undergraduate student of the Faculty of Economics and Business, University of Jember and is a person who is currently or has at least once used a sharia investment application product. The total number of undergraduate students of the Faculty of Economics and Business according to the Information BPKH The University of Jember in the 2020/2021 odd semester data as of September 16, 2020 , as many as 3,562 students spread across the University of Jember. This study uses the Slovin formula tocalculate the sample to be taken with an error rate of $10 \%$, it can be seen that the respondents in this study amounted to 97 people.

Primary data that has been taken in this research will be converted from ordinal data to interval data using the Interval Successive Method. Then, the data is processed using SPSS with multiple linear regression analysis. After that, the data processing is continued with a simultaneous statistical test and partial significance test to determine the effect of the theory of planned behavior on student investment interest in sharia fintech.

\section{RESULT AND DISCUSSION}

\subsection{Multiple Linear Regression Analysis}

$$
Y=3.936+0.536 X 1+0.257 X 2+0.042 X 3
$$

The formula above shows a constant value of 3.936 which means that the current state of the student investment interest variable has not been influenced by another variable, namely the attitude variable, subjective norm and behavioral control. If the independent variable does not exist, then the investment interest variable does not change. The value of the coefficient of determination obtained in this study amounted to 0.284 . This figure shows that student investment interest in fintech sharia is influenced by attitudes, subjective norms, and behavioral control by $28.4 \%$. While the remaining $71.6 \%$ is influenced by other variables that are not included in this research model.

Meanwhile, the regression coefficient value X1 of 0.536 indicates that the attitude variable has a positive influence on student investment interest, then any increase in the attitude variable will affect the 
student interest variable with the assumption that other variables are not examined in this study. Regression coefficient value X2 of 0.257 indicates that the subjective norm variable has a positive influence on student investment interest, so any increase in subjective norm will affect student interest variables with the assumption that other variables are not examined in this study. Then for the value of the regression coefficient X3 of 0.042 indicates that the behavioral control variable has a positive influence on student investment interest, then any increase in the behavioral control variable will affect the student interest variable with the assumption that other variables are not examined in this research. The detailed result of multiple linear regression analysis is shown in Table 1 below.

Table 1. Multiple Linear Regression Analysis Test

\begin{tabular}{|c|c|c|c|c|c|}
\hline \multirow{2}{*}{$\mathrm{N}$} & \multicolumn{2}{|c|}{ Unstandard. Coeff. } & \multirow{2}{*}{$\begin{array}{l}\text { Stand. } \\
\text { Coeff. }\end{array}$} & \multirow{2}{*}{$\mathrm{t}$} & \multirow{2}{*}{ Sig. } \\
\hline & B & Std. Error & & & \\
\hline $\mathrm{C}$ & 3,936 & 1,601 & - & 2,459 & 0,016 \\
\hline $\mathrm{X}_{1}$ & 0,536 & 0,120 & 0,454 & 4,460 & 0,001 \\
\hline $\mathrm{X}_{2}$ & 0,257 & 0,078 & 0,285 & 3,273 & 0,001 \\
\hline $\mathrm{X}_{3}$ & 0,042 & 0,085 & 0,050 & 0,486 & 0,628 \\
\hline
\end{tabular}

\subsection{Hypothesis Test Result}

\subsubsection{Simultaneous Statistical Test}

Simultaneous statistical test ( $F$ test) is used to jointly test the presence or absence of the influence of the independent variable on the dependent variable. The significance value for the effect of $\mathrm{X} 1, \mathrm{X} 2$, and $\mathrm{X} 3$ is known simultaneously to $\mathrm{Y}$ is $0.000 \mathrm{~F}$ table 2.70. The results of this $F$ test can be concluded that $\mathrm{H} 0$ rejected, which means that there is a significant influence between the independent variables, namely attitudes, subjective norms and behavioral control on the dependent variable, namely student investment interest in fintech sharia.

\subsubsection{Partial Significance Test}

This test is used to determine how far the influence of an independent variable individually, namely attitude (X1), subjective norm (X2) and behavioral control (X3) on student investment interest in fintech sharia which is the dependent variable in this study. The basis for decision making in this $\mathrm{T}$ test is if the value of $\mathrm{t}$ count $<\mathrm{t}$ table then the variable independent has no effect on the dependent, and vice versa if $t$ count $>t$ table then the independent variable affects the dependent variable.
The partial significance test results are obtained as presented in Table 2.

Table 2. Partial Significance Test Result

\begin{tabular}{lccccl}
\hline $\mathrm{N}$ & $\mathrm{B}$ & $\mathrm{T}_{\text {hitung }}$ & $\mathrm{T}_{\text {tabel }}$ & Sig. & Alpha \\
\hline $\mathrm{X}_{1}$ & 0,536 & 4,460 & 1,98580 & 0,000 & 0,05 \\
$\mathrm{X}_{2}$ & 0,257 & 3,273 & 1,98580 & 0,001 & 0,05 \\
$\mathrm{X}_{3}$ & 0,042 & 0,486 & 1,98580 & 0,628 & 0,05 \\
\hline
\end{tabular}

\subsection{Discussion}

The results of this study indicate that attitudes have an influence on student investment interest through: fintech sharia which is shown from the results of the analysis of the partial significance test (table 2) is $0.00<0.05$ and $4,460>1.98580$. This value indicates that attitude has a positive and partially significant effect on student investment interest through fintech sharia in the faculty of economics and business, university of jember. The higher the student's attitude is determined by the belief in the consequences of investing infintech sharia, the higher the interest of students to invest through fintech the sharia.

The respondent's answer with the highest average on this questionnaire is in the statement $\mathrm{x} 1.1$, namely the interest in seeing shariabased investment products using applications or platforms shows the highest average value with a total of 3.69. Thus, it can be concluded that the interest of respondents when viewing islamic investment products using applications or platforms is very good, so that it is in accordance with behavioral belief indicators. The attitude taken by the respondents in this study is in accordance with the opinion [15], the attitude of a muslim who has processes and principles where decision making they will do first through alternative evaluations, namely refusing harm in transactions, the perception of the need to benefit in the future, as well as perceptions mardhaillah via app fintech in accordance with islamic sharia to achieve the pleasure of allah swt. In search of sustenance.

Subjective norm at this study has a results that an influence on student investment interest through fintech sharia which is shown from the results of the analysis of the partial significance test is $0.001<0.05$ and 3.273> 1.98580, where tcount is greater than compared to $\mathrm{t}$ table. This value indicates that subjective norms also have a positive and partially significant effect on student investment interest through fintech sharia in the Faculty of Economics and Business, University of Jember. The results of the questionnaire in this study had an average 
disagree, with the highest average statement being 2.56 at X2.4. The statement relates to the use of sharia investment products with fintech for following the advice of a friend. These results indicate the existence of normative beliefs and students' motivation to use sharia investment products using applications or platforms by following suggestions from friends.

Behavioral control in the results of this study shows that there is no effect on student investment interest through fintech sharia which is shown from the results of the analysis of the partial significance test is $0.628>0.05$ and $0.486<1.98580$, where the $\mathrm{t}$ count is smaller than the table. This value indicates that behavioral control does not have a partial effect on student investment interest. In other words, the high interest of students from the Faculty of Economics and Business, University of Jember to invest infintech Sharia is not influenced by behavioral control which is a person's perception of whether or not that person is easy to invest in fintech sharia. This can be interpreted that respondents have a perception that investing in fintech Sharia is a behavior that is not easy to do. Based on Rotter's opinion [4], behavioral control can change depending on the situation and the type of behavior that will be carried out by someone that allows respondents to have an interest in investing not because of behavioral control but because of other factors.

\section{CONCLUSION}

The results of this study are attitudes and subjective norms have a positive and significant influence on student investment interest through fintech sharia in the Faculty of Economics and Business, University of Jember. This proves that trust and evaluation, as well as suggestions from the closest people can have an influence on individuals, especially students, to invest in financial institutions fintech sharia. While behavioral control at this research does not have a partial influence on student investment interest through fintech sharia in the Faculty of Economics and Business, University of Jember.

\section{REFERENCES}

[1] Kustodian Sentral Efek Indonesia, Data Statistik Pertumbuhan Investor (Single Investor Identification). Jakarta: PT. Kustodian Sentral Efek Indonesia, 2021.
[2] D. N. Utami, Wow 70 Persen Investor Pasar Modal Indonesia Berusia Muda [Internet], [cited 2020 Jan 4] Available from: Https://Market.Bisnis.Com/Read/20201027/7/1 310588/Wow-70-Persen-Investor-Pasar-ModalIndonesia-Berusia-Muda. 2020.

[3] D. R. Pratiwi, Pentingnya Perkembangan Financial Technology Dalam Mendorong Keuangan Inklusif Sudah Tepatkah Penurunan Tarif Pajak Persen. Badan Keahlian DPR RI 3, 2018.

[4] Mahyarni. 2013. "Theory of Reasoned Action Dan Theory of Planned Behavior (Sebuah Kajian Historis Tentang Perilaku)". Jurnal ElRiyasah vol.4, no.1, pp.13.

[5] S. Mardison, "Konformitas Teman Sebaya Sebagai Pembentuk Perilaku Individu," Jurnal Al-Taujih: Bingkai Bimbingan Dan Konseling Islami vol.2, no.1, pp.78-90, 2016.

[6] PT. Eastspring Investments Indonesia. "Spring Smart Pentingnya Alokasi Aset,” pp.1-5. 2018

[7] A. E. Savitri, "Analisis Perbedaan Reaksi Pasar Modal Sebelum Dan Sesudah Adanya Perusahaan Financial Technology," Skripsi, Universitas Islam Maulana Maliki Ibrahim, 2013.

[8] A. N. Hidayati, "Analisis Dan Relevansinya Dengan Ekonomi Islam," Jurnal Ekonomi Islam, vol.8, no.2, pp.227-42, 2017.

[9] S. Maulidah, "Intensi Mahasiswa Untuk Berinvestasi Di Bursa Efek Indonesia (Kajian Dengan Menggunakan Technology Acceptance Model)" Skripsi, Universitas Negeri Semarang Semarang, 2017.

[10] Z. Ahsan, "Hubungan Minat Fotografi Dengan Motivasi Bekerja Pada Anggota Organisasi Jhepret Club Universitas Islam Negeri (UIN) Maulana Malik Ibrahim Malang" Skripsi, UIN Maulana Malik Ibrahim Malang, 2012.

[11] M. Ansori, "Perkembangan dan Dampak Financial Technology (Fintech) Terhadap Industri Keuangan Syariah Di Jawa Tengah," Wahana Islamika: Jurnal Studi Keislaman, vo.5, no.1, pp. 31-45, 2019.

[12] Penyelenggara Fintech Lending Terdaftar dan Berizin di OJK per 7 Desember 2020. [Internet] 2020. Available from: Ojk.go.id. https://www.ojk.go.id/id/kanal/iknb/financial- 
technology/Pages/Penyelenggara-FintechLending-Terdaftar-dan-Berizin-di-OJK-per-7Desember-2020.aspx

[13] H. Machrus, and U. Purwono. "Pengukuran Perilaku Berdasarkan Theory Of Planned Behavior". Insan Media Psikologi., vol.12, no.01, pp. 64-72, 2010.

[14] A. Novitarani, dan R. Setyowati. Analisis Crowdfunding Syariah Berdasarkan Prinsip Syariah Compliance Serta Implementasinya Dalam Produk Perbankan Syariah. 2018.

[15] N. Ramdhani, "Penyusunan Alat Pengukur Berbasis Theory Of Planned Behavior.Buletin Psikologi" vol. 19, no.2, pp. 55-69, 2011.

[16] R. F. Subekhi, and R. T. Ratnasari. Religiousity And Theory Planned Behaviour Towards Intention To Give Infaq.Jurnal Ekonomi Dan Bisnis Islam, 2017.

[17] E. R. Emly, Perilaku Menggunakan Jasa Pembuatan Skripsi Ditinjau Dari Sikap Fishbein dan Ajzen. Pekanbaru: Repository UIN Suska. 2015. 